logos_i_ethos_2014_2_(37), s. 137-152

DOI: http://dx.doi.org/10.15633/lie.800

\title{
Marek Jakubiec
}

\section{O relacji pomiędzy filozofią nauki a jurysprudencją w świetle problematyki naturalizacji prawa}

Filozofia nauki i filozofia prawa (w niniejszym tekście utożsamiana $\mathrm{z}$ jurysprudencją ${ }^{1}$ ) to dwie dyscypliny, w odniesieniu do których może powstać wrażenie braku jakiegokolwiek istniejącego pomiędzy nimi powiązania. Tymczasem z punktu widzenia współczesnej jurysprudencji sytuacja okazuje się zgoła odmienna. Owo wrażenie jest jednak przynajmniej częściowo uzasadnione. O ile wszak zadaniem pierwszej z nich jest m.in. podejmowanie analiz dotyczących nauki i poznania naukowego, o tyle przedmiotem drugiej jest w szczególności dociekanie charakteru prawa i związanych z nim problemów teoretycznych.

Wraz z rozwojem podejścia realistycznego w jurysprudencji, a więc propozycji takich, jak między innymi amerykański i skandynawski realizm prawny czy koncepcja Leona Petrażyckiego, osiągnięcia szeroko rozumianych nauk empirycznych stały się przedmiotem zainteresowania ze strony filozofii prawa.

Tematem niniejszego artykułu będzie przedstawienie powodów zaistnienia takiego stanu rzeczy, jak również racji, z powodu których

1 Termin „jurysprudencja” nie jest do końca jednoznaczny, niemniej jednak jednym z funkcjonujących jego znaczeń jest filozoficzna refleksja nad prawem. Zob. np. J. Austin, Lectures on jurisprudence or philosophy of the positive law, Clark, New Jersey 2005. 
znajomość filozofii nauki może okazać się przydatna dla współczesnych przedstawicieli koncepcji zaliczanych do nurtu realizmu prawnego. W związku z tym niezbędne jest przedstawienie najistotniejszych historycznych propozycji dotyczących natury prawa i metodologii prawniczej, jakie pozostawili wybrani przedstawiciele dwudziestowiecznego realizmu, co uczynię w części pierwszej. Będzie ona stanowić wprowadzenie niezbędne dla dalszego wywodu, na którego treść złoży się prezentacja wybranych aspektów współczesnych debat na temat naturalizacji. Wskażę w nim przede wszystkim, jakie konsekwencje dla związanej ze współczesnym realizmem problematyki naturalizacji prawa może mieć stanowisko w kwestii wartości poznawczej nauki, które stanowi fallibilizm. Podjęta zostanie też próba eksplikacji relacji istniejącej pomiędzy prawem a naukami empirycznymi i psychologią, jak i ukazania możliwości spojrzenia $\mathrm{z}$ interesującej perspektywy na wielowiekowy, kluczowy dla licznych filozofów prawa problem „istoty prawa”2.

\section{Znaczenie nauk empirycznych dla jurysprudencji w świetle wybranych nurtów realistycznych w prawoznawstwie}

\subsection{Realizm amerykański}

Z rozwojem realizmu prawnego wiąże się ściśle ruch realizmu amerykańskiego, zapoczątkowany przez Olivera Wendella Holmesa. W swym artykule Thepath of the law ów sędzia pracujący w Stanach Zjednoczonych przedstawił propozycję odmienną od wielu dotychczasowych koncepcji prawa, uznając, że jest nim nie zbiór przepisów, reguł czy nakazów Boga, lecz przede wszystkim zachowanie sędziów (przejawiające się zwłaszcza w wydawaniu wyroków) ${ }^{3}$. Metoda jurysprudencji polega więc na kierowaniu się sposobem myślenia „złego człowieka”, dla którego prawem

2 Jest to zagadnienie kontrowersyjne, warto bowiem postawić pytanie, na ile odnalezienie takiej „istoty” jest w ogóle możliwe. Nie zmienia to jednak faktu, że dla licznych filozofów wciąż stanowi ono cel dociekań, m.in. dla wspominanego w tym tekście Petrażyckiego.

O. Holmes, The path of the law, „Harvard Law Review” 1987 vol. 10 no. 8, ss. 457-458. 
jest to, co uczynią sędziowie, jeżeli popełni on przestępstwo ${ }^{4}$; nie jest natomiast zainteresowany etycznymi podstawami przepisów prawa ani ich ratio, pragnie bowiem przede wszystkim uniknąć sankcji. Jego celem jest zatem dokonywanie predykcji dotyczących decyzji sędziego, przed którym w takiej sytuacji stanie. Z opinii Holmesa wynika, że w taki sam sposób o prawie winni myśleć filozofowie prawa, którzy chcą dociekać jego „istoty”. Jaka może być konsekwencja takiego ujęcia metodologii nauk prawnych?

Okazuje się, że klasycznie rozumiana jurysprudencja nie dostarcza wystarczającej ilości narzędzi pomocnych do prowadzenia tego typu analiz, w związku z czym konieczne staje się sięgnięcie do aparatu dyscyplin opisujących ludzkie zachowania z różnych aspektów. Kluczowe jest bowiem "prawo w działaniu” (law in action), a nie "prawo w księgach" (law in books). Pierwsze z nich należy do szeroko rozumianej sfery rzeczywistości empirycznej, której badanie podlega regułom metodologicznym stosowanym przez przedstawicieli nauk przyrodniczych, psychologii (jak również socjologii). Skoro więc prawo stanowi pewnego rodzaju „zbiór” zachowań przedstawicieli wymiaru sprawiedliwości, to jest ono rzeczywistym faktem, którego istoty należy dociekać nie poprzez abstrakcyjne spekulacje, lecz przez odwoływanie się do osiągnięć dyscyplin pozwalających opisywać między innymi procesy psychiczne prowadzące do podjęcia decyzji przez człowieka, a w interesującym nas kontekście sędziego. Uwagi Holmesa pozwalają więc na stwierdzenie, że prawo jest redukowalne do sfery psychicznej osób stosujących prawo. W konsekwencji jurysprudencja okazuje się dyscypliną wyłącznie deskryptywną, a problem obowiązywania norm prawnych przestaje być zagadnieniem filozoficznym. Wniosek, jaki wypływa z tych rozważań, można ująć następująco: ponieważ jeśli chcemy zrozumieć, czym jest prawo, winniśmy patrzeć na nie z perspektywy konsekwencji, jakie na jego podstawie może ponieść osoba nieprzestrzegająca pewnych norm ${ }^{5}$, realizując to zadanie, nie należy posiłkować się metafizycznymi 
spekulacjami czy analizą pojęciową, lecz aparatem nauk behawioralnych sensu largo.

Trzeba jednak w tym miejscu podkreślić, że dociekanie natury czy istoty prawa nie stanowiło celu Holmesa i innych amerykańskich realistów. Był to ruch pragmatyczny, którego przedstawiciele nie wykazywali szczególnego zainteresowania tego typu zagadnieniami, istotnymi z punktu widzenia filozofii prawa. Nie zmienia to jednak faktu, że dziś postrzegany jest jako jeden $\mathrm{z}$ najważniejszych nurtów współczesnej jurysprudencji.

\subsection{Istota ujęcia Petrażyckiego}

Nieco odmiennie na problematykę istoty prawa zapatrywał się jego polski teoretyk, Leon Petrażycki. Pomimo że jego koncepcji nie sposób zaklasyfikować jako jednoznacznie realistycznej, zasługuje ona w tym miejscu na uwagę. W interesującym nas kontekście jego refleksje można streścić następująco: prawem jest w rzeczywistości nie zbiór reguł stanowiących wynik procesu działania władzy ustawodawczej, lecz zespół procesów mentalnych, w których pozycję szczególną zajmują emocje. Normy prawne, roszczenia czy obowiązki to wyłącznie projekcje emocjonalne podmiotów, które doznają pewnych przeżyćc.

Zrozumienie natury stanów psychicznych wymaga introspekcji, która, jak twierdzi Petrażycki, jest niezbędnym elementem w procesie poznawania prawa. Nie stanowi jednak jego wyłącznego elementu, nie mniej ważna jest bowiem obserwacja zachowań jednostek dokonywana przez inne osoby ${ }^{7}$.

Koniecznym elementem badań poświęconych naturze prawa okazuje się w związku z tym analiza owych emocji, w szczególności tych, które polski filozof określał mianem „atrybutywnych”. Niezwykle przydatne

$6 \quad$ K. Motyka, Petrażycki Leon, [w:] Powszechna encyklopedia filozofii, Polskie Towarzystwo Tomasza z Akwinu [wersja internetowa: http://www.ptta.pl/pef/pdf/p/petrazycki.pdf].

$7 \quad$ L. Petrażycki, Wstęp do nauki prawa i moralności, [w:] tegoż, O nauce, prawie i moralności: pisma wybrane, Warszawa 1985, s. 180-181. 
dla jurysprudencji stają się więc narzędzia psychologii, a ze współczesnej perspektywy również neurobiologii czy biologii ewolucyjnej. Filozofowie prawa nie dysponują wszak odpowiednią metodą, która byłaby autonomiczna w stosunku do metod tych nauk.

\subsection{Skandynawski realizm prawny}

Zbliżone spojrzenie reprezentowali filozofowie skandynawscy, skupieni wokół Axela Hägerströma, tworzący szkołę skandynawskiego realizmu prawnego. Istotne w kontekście prezentowanej przez nich wizji prawa są jej filozoficzne podstawy, którymi były w pierwszym rzędzie pozytywizm logiczny oraz monizm materialistyczny. Będący konsekwencją przyjęcia tez głoszonych przez przedstawicieli pierwszego z nich antymetafizycyzm skłonił Skandynawów do krytycznej refleksji nad istotą pojęć prawnych i rolą prawa $\mathrm{w}$ społeczeństwie. Jedną $\mathrm{z}$ istotnych tez głoszonych przez pozytywistycznie zorientowanych przedstawicieli i zwolenników Koła Wiedeńskiego była weryfikacjonistyczna koncepcja znaczenia. Jej istota sprowadzała się do stwierdzenia, iż sensem zdania jest metoda jego weryfikacji. Tym samym te zdania, których nie można zweryfikować na drodze empirycznej, zostają uznane za bezsensowne. Oczywiście, z racji charakteru metafizyki jako dyscypliny filozoficznej, której przedstawiciele stawiają sobie zasadniczo za cel poszukiwanie odpowiedzi na pytanie o istote „bytu jako bytu”, konfrontacja formułowanych tez z obserwacją jest zazwyczaj niemożliwa. W opinii pozytywistów są one więc "nadużyciem językowym” pozbawionym jakiegokolwiek sensu.

Co istotne, pojęcia prawne zostają przez Alfa Rossa, przedstawiciela realizmu skandynawskiego, którego poglądy stanowią interesującą egzemplifikację sposobu myślenia Skandynawów, uznane za specyficzne pojęcia metafizyczne. Istotą jurysprudencji - podobnie jak w przypadku dwóch powyższych propozycji Holmesa i Petrażyckiego - jest nie dociekanie abstrakcyjnej natury regulacji prawnych i tworzących je przepisów, lecz badanie faktów powiązanych z prawem. Analiza filozoficznoprawna powinna więc dotyczyć przede wszystkim 
aktualnych i przyszłych odczuć i zachowań ludzi (zwłaszcza sędziów; poglądy Rossa były w tym aspekcie szczególnie bliskie realizmowi amerykańskiemu). Ross był świadom istotnej roli, jaką pełni prawo, ujawniającej się poprzez świadomość obywateli co do faktu obowiązywania pewnych norm. Uznał jednak, że pojęcia prawne są pozbawione jakiegokolwiek znaczenia ${ }^{8}$, a jedyna odpowiadająca im rzeczywistość wynika $z$ tego, że są one fenomenem psychicznym, w perspektywie naturalistycznej należącym do sfery rzeczywistości materialnej. Jako takie winny być one badane w sposób empiryczny. Aspektem „nauki prawa”, poddającym się badaniu naukowemu w świetle postulatów filozofii neopozytywistycznej, okazuje się zatem stosunek psychiczny jednostek do dyrektyw; w opinii Rossa normy prawne są bowiem dyrektywami „pozostającymi w pewnej relacji do faktów społecznych”. Jak łatwo przewidzieć, jest to pogląd kontrowersyjny; wyrazem tego jest fakt, że spotkał się on z szeroką krytyką, a jednym z adwersarzy Rossa stał się wpływowy dwudziestowieczny filozof prawa, Herbert Lionel Adolphus Hart ${ }^{10}$.

\section{Projekty naturalizacji prawa i ich trudności}

Krótko zaprezentowane powyżej nurty stanowią przykłady ilustrujące realistyczne spojrzenie na prawo jako fakt możliwy do badania na szeroko rozumianej drodze empirycznej. Sprawia to, że mogą one być rozpatrywane jako modele naturalizacji prawa, pomimo iż ich przedstawiciele zazwyczaj nie określali w ten sposób swoich poglądów. Pod sformułowaniem "naturalizacja prawa” będą rozumiane propozycje wykorzystywania osiągnięć współczesnej nauki (najczęściej ujmowanej szeroko) do analizy problemów prawnych.

8 Zob. A. Ross, Tĥ-Tĥ, „Harvard Law Review” 1957 vol. 70, s. 818.

9 A. Ross, Directives and norms, London 1968, s. 82 (cytat za: J. Stelmach, R. Sarkowicz, Filozofia prawa XIX i XX wieku, s. 117).

${ }_{10}$ Zob. H. L. A. Hart, Scandinavian realism, „The Cambridge Law Journal” 1959 vol. 17 no. 2 , s. $236 \mathrm{i} \mathrm{n}$. 
W związku z wielonurtowością tego typu koncepcji warto odróżnić naturalizację sensu stricto i sensu largo ${ }^{11}$. Podczas gdy pierwsza zakłada co do zasady potrzebę aplikacji nauk biologicznych, druga rozszerza katalog relewantnych $\mathrm{z}$ tego punktu widzenia dyscyplin, wskazując na użyteczność również m.in. psychologii, matematyki i ekonomii. W niniejszym tekście będziemy zainteresowani pierwszą z nich oraz tymi modelami naturalizacji sensu largo, które wskazują na istotność badań psychologicznych. Konsekwencją przedstawionych powyżej tez głoszonych przez reprezentantów szeroko rozumianych nurtów realistycznych jest bowiem zwrócenie się przede wszystkim $w$ stronę tych dyscyplin, ze względu na fakt, iż to ich przedstawiciele dysponują odpowiednim aparatem naukowym, za pomocą którego możliwe jest badanie motywów ludzkich zachowań czy emocji.

Rozpatrywanie prawa jako „faktu” niesie ze sobą jednak poważne konsekwencje metodologiczne. Zadaniem filozofów prawa staje się bowiem nie tyle dokonywanie językowej analizy obowiązujących przepisów, dociekanie natury stanowionych przez władzę regulacji czy rozważanie relacji istniejącej pomiędzy prawem a moralnością, ile podejmowanie próby opisu zjawisk wiążących się z istnieniem regulacji prawnych. Stwierdzenie to można zilustrować poprzez odwołanie do jednego z kluczowych pojęć prawnych, jakim jest „obowiązywanie”. $\mathrm{W}$ świetle niektórych propozycji realistycznych istotne okazuje się prowadzenie badań nad reakcjami psychicznymi osób na pewne dyrektywy, jak na przykład zakaz naruszania cudzej własności. Zadanie prawodawcy jawi się natomiast jako swoista „inżynieria społeczna”, polegająca na odpowiednim zarządzaniu owymi emocjami w taki sposób, by zapewnić istnienie względnego ładu społecznego ${ }^{12}$.

O ile w ramach „klasycznie” pojmowanej jurysprudencji ${ }^{13}$ zadaniem teoretyków i filozofów prawa miało być podejmowanie analizy istoty

11 W. Załuski, Game theory in jurisprudence, Kraków 2013, s. 289.

12 Zob. J. Bjarup, The philosophy of scandinavian legal realism, „Ratio Juris” 2005 vol. 18, s. 14 .

13 Oczywiście takie określenie nie jest pozbawione kontrowersji, niemniej jednak wydaje się, iż odróżnienie propozycji realistycznych od dominujących w XIX i XX wieku nurtów, jak np. 
prawa poprzez specyficzne metody prawnicze, np. analizę pojęciową (nurt Begriffsjurisprudenz), o tyle w ramach podejścia realistycznego metoda prawnicza zostaje zastąpiona przez metody nauk umożliwiające formułowanie opisu owych faktów ${ }^{14}$.

W konsekwencji, takie przedstawienie problematyki filozoficznoprawnej ma istotne znaczenie z punktu widzenia filozofii nauki, jak również filozofia nauki okazuje się dyscypliną relewantną z punktu widzenia jurysprudencji. Jeśli bowiem metodologia prawa jest w istocie tożsama z metodologią dyscyplin empirycznych, można pokusić się o stwierdzenie, że filozofia prawa staje się dyscypliną bardzo zbliżoną do filozofii nauki, a być może nawet z nią tożsamą. W konsekwencji jednak jurysprudencja dziedziczy liczne problemy rozważane dotychczas jedynie w ramach filozofii nauki, takie jak możliwość aplikacji osiągnięć nauki w praktyce, problem realizmu i antyrealizmu, ontologiczny status obiektów teoretycznych czy wartość poznania naukowego. Zważywszy na fakt, że prawo jest jednym z najistotniejszych regulatorów życia społecznego, pytanie o wartość poznawczą dyscyplin pozwalających formułować wyrażenia o charakterze deskryptywnym, mające znaczenie dla jego rozumienia, okazuje się istotne zarówno z teoretycznego, jak i praktycznego punktu widzenia. Szczególnego znaczenia nabierają w tym kontekście poglądy filozoficzne podważające intuicyjne przekonanie o adekwatności naukowego opisu świata, a dokładniej o jego zgodności z rzeczywistością, tak więc prawdziwości w sensie klasycznym.

Zanim jednak przejdziemy do omówienia tej problematyki, warto zwrócić uwagę na kilka innych problemów, jakie wiążą się z utożsamieniem sformułowań preskryptywnych, jakimi są przepisy prawa, ze sformułowaniami deskryptywnymi, charakterystycznymi dla dyscyplin na-

pozytywizmu czy niepozytywizmu Dworkina w kontekście niniejszego artykułu jest (choćby częściowo) uzasadnione.

14 Jest oczywiście kwestią dyskusyjną, czy swego rodzaju „autonomiczna metoda prawoznawstwa" istnieje. Niemniej jednak w świetle przedstawionych realistycznych filozofii prawa wydaje się, że niezależnie od stanowisk przyjętych przez dyskutantów, wszelka metodologiczna autonomia prawnicza znika. 
ukowych. Przede wszystkim próby sprowadzenia refleksji nad prawem do badań charakterystycznych dla nauk empirycznych czy psychologii są kontrowersyjne nie tylko z powodu metodologicznych trudności, jakie wiążą się z aplikacją ich osiągnięć do badania „stanów relewantnych prawnie", lecz również dlatego, że rola prawa jest całkowicie odmienna od funkcji pełnionej przez naukę. $\mathrm{O}$ ile jednym z zadań prawa, w pewnym uproszczeniu, jest regulowanie zachowań członków społeczeństwa, o tyle nauka winna dostarczać rzetelnego opisu rzeczywistości. Jeśli prawo okazuje się tożsame z pewnymi faktami, pytanie o jego rolę musi zostać postawione na nowo. Prawdopodobną odpowiedzią będzie stwierdzenie, w duchu filozofii realistów skandynawskich, że prawo polega na odpowiednim „zarządzaniu emocjami” obywateli, w taki sposób, by nie podejmowali oni niekorzystnych z punktu widzenia dobra wspólnego działann ${ }^{15}$. Staje się więc ono w istocie - jak już wskazywaliśmy - dyscypliną deskryptywną, a jego zadaniem okazuje się dostarczenie środków pozwalających na realizację tego celu. To konsekwencja redukcjonistycznego poglądu na naturalizację prawa, którą trudno zaakceptować. Ponadto propozycje przedstawione powyżej nie są pozbawione niespójności, czego dobrą egzemplifikację stanowi paradoks, z którym mamy do czynienia w wizji Petrażyckiego. Jak wspomniano w pierwszej części niniejszego artykułu, istnieć ma prawo, stanowiące pewien rodzaj emocji. Emocje te mają jednak swoją genezę, a jest nią działanie prawodawcy. Ten natomiast ma kierować się regułami racjonalności instrumentalnej ${ }^{16}$, a nie emocjami. Jaka jednak może być podstawa prawna jego działań, skoro istota prawa okazuje się tożsama z emocjami, które $\mathrm{w}$ działaniach $\mathrm{w}$ pełni racjonalnych winny być nieobecne? Czy zatem działanie prawodawcy okazuje się bezprawne? Z drugiej strony, Petrażycki zapewne zdawał sobie sprawę, iż uznanie, że prawodawca kieruje się emocjami, stanowiłoby poważną trudność, podważającą wartość jego propozycji. Niemniej jednak swego rodzaju fundacjonizm epistemo-

15 Zob. J. Bjarup, The philosophy of scandinavian legal realism, s. 14.

16 Zob. B. Brożek, Some remarks on the naturalization of law, Kraków 2010, s. 78 (Studies in the Philosophy of Law, V). 
logiczny w kwestii istoty prawa doprowadził go sformułowania problematycznej propozycji.

Z tego rodzaju fundacjonistycznym nastawieniem mamy do czynienia we wszystkich przedstawionych w pierwszej części artykułu propozycjach. Niestety, „mit istoty prawa”"17, wciąż jest przedmiotem dociekań przedstawicieli jurysprudencji, mimo że część z nich zapewne negowałaby słuszność takiej postawy. Wyjątkiem jest Petrażycki, który wprost artykułuje swoje pragnienie jej odnalezienia ${ }^{18}$, zauważając jednak, że dotychczasowe projekty filozoficzne nie sprostały temu zadaniu. Rossa z kolei, jako filozofa inspirowanego rozważaniami pozytywistów logicznych, antymetafizyczna i empiryczna wizja prawa prowadzi na manowce równie fundacjonistycznej propozycji, wedle której jedyna filozofia prawa niepozbawiona sensu to zbiór zdań, pozostających w bezpośredniej relacji logicznej do zdań spostrzeżeniowych. Podobnie więc jak Rudolf Carnap, Moritz Schlick czy Hans Reichenbach ulega on pokusie posiadania niezawodnej podstawy wszelkich stwierdzeń, którą miały stanowić zdania obserwacyjne. Krytyka filozoficzna szybko jednak ujawniła liczne problemy ich koncepcji, w wyniku czego tak empiryzm logiczny, jak i skandynawski realizm prawny utraciły znaczenie $^{19}$. Nie oznacza to jednak, że głoszone przez ich przedstawicieli tezy przestały być przedmiotem filozoficznej refleksji. Skandynawski model naturalizacji okazuje się przykładem ujawniającym trudności wiążące się z projektem naturalizacji prawa, który wymaga bardziej wyrafinowanej metodologii, niż ta, która została zaproponowana przez Rossa.

Podobne zarzuty można sformułować również wobec predykcyjnej metodologii Holmesa. Pomimo iż (jak wskazywano wcześniej) trudno

17 B. Brożek, Normatywność prawa. Szkic teorii (tekst dostępny na: http://biolawgy.files. wordpress.com/2010/06/normatywnosc.pdf). 1924, s. 30-31.

L. Petrażycki, O pobudkach postępowania i o istocie moralności i prawa, Warszawa

19 Zob. J. Dalberg-Larsen, Alf Ross and the sociology of law, „Scandinavian Studies In Law" 2005 vol. 48, s. 50; w kwestii problematyki aktualności realizmu skandynawskiego w szczególności: B. Leiter, Naturalism in legal philosophy, [w:] Stanford encyclopedia of philosophy, ed. E. N. Zalta, Stanford 2012, <http://plato.stanford.edu/entries/lawphil-naturalism/> (30.01.2014). 
posądzać go o szczególne inklinacje filozoficzne ${ }^{20}$, również zaproponowaną przez niego wizję prawa można określić mianem redukcjonistycznej.

Trudności wiążące się z powyżej zaprezentowanymi modelami ukazują, że poszukiwanie bezwzględnej podstawy epistemologicznej filozofii prawa i samego prawa nie jest postawą trafną ${ }^{21}$. Nawet wartościowe spostrzeżenia natury metodologicznej tracą bowiem znaczenie, gdy na jaw wychodzi fakt, iż podstawa, na której zostały zbudowane, jest błędna. Postulowanie tożsamości prawa i dyscyplin naukowych okazuje się trudnością nie tylko z powodów „czysto” metodologicznych, lecz również filozoficznych. Rozmaitość stanowisk w ramach filozofii nauki, która co najmniej w części miałaby okazać się tożsama z filozofią prawa, ukazuje bowiem, że pewna naiwna odmiana realizmu naukowego, stojąca za tymi modelami, jest nie tylko poddawana krytyce, ale też znajduje silną opozycję w postaci filozoficznie ugruntowanych poglądów, podzielanych przez wielu myślicieli, jakie stanowią antyrealizm czy fallibilizm ${ }^{22}$. Pewne ich tezy mogą okazać się istotne z punktu widzenia owej naturalizacji, podważając nie tylko możliwość pełnego utożsamienia prawa $\mathrm{z}$ innymi dyscyplinami, lecz być może również sens wszelkich tego rodzaju badań.

\section{Programy naturalizacji prawa wobec problemów z zakresu filozofii nauki}

W kwestii statusu poznawczego nauki, jak wspomnieliśmy, wykrystalizowała się mnogość stanowisk. Z jednej strony realizm naukowy, (zwłaszcza w wersji naiwnej) głoszący, że nauka zapewnia nam rzeczywiste poznawanie świata fizycznego, poddawany jest wciąż krytyce nie

20 Zob. K. Llewellyn, Some realism about realism: Responding to Dean Pound, „Harvard Law Review" 1931 vol. 44 no. 8, s. 1222-1223.

${ }^{21}$ Ogólne informacje na temat fundacjonizmu, jak również krytykę tego podejścia w epistemologii można znaleźć w: M. Heller, Przeciw fundacjonizmowi, [w:] tegoż, Filozofia i wszechświat, Kraków 2006, s. 82-101.

22 Zob. B. Reed, How to think about fallibilism, „Philosophical Studies: An International Journal for Philosophy in the Analytic Tradition” 2002 vol. 107 no. 2, s. 143. 
tylko przez filozofów, lecz również przedstawicieli nauk empirycznych ${ }^{23}$, z drugiej od początku namysłu nad poznawczymi możliwościami człowieka pojawiały się głosy, iż są one wysoce ograniczone bądź w ogóle nie istnieją. To ostatnie stanowisko zyskiwało na znaczeniu równie szybko, jak szybko rozgłos zyskiwały pierwsze peany na cześć nauki i uzyskanych dzięki niej korzyści. W związku z jej dynamicznym rozwojem, z jakim Europejczycy mieli do czynienia od XVII, ale zwłaszcza od XIX wieku, nastąpił także rozwój refleksji nad powiązanymi z nią problemami, co doprowadziło do wykształcenia się odrębnej dyscypliny, jaką jest filozofia nauki. Jednym z problemów, jaki znalazł się wśród kluczowych zagadnień rozważanych w jej ramach w minionym stuleciu, stała się wartość poznawcza nauki i powiązane $\mathrm{z}$ nią kwestie dotyczące metody naukowej. Istotne okazały się rozważania neopozytywistyczne, których krytyka pozwoliła na sformułowanie wielu interesujących propozycji. Przykładem jednej z nich stała się hipotetyczno-dedukcyjna wizja rozwoju nauki przedstawiona przez Karla Poppera. Nie ma miejsca w niniejszym artykule na szczegółowe przedstawienie poglądów austriackiego myśliciela, na temat których powstała niezliczona liczba tekstów. Kluczowy z punktu widzenia naszych rozważań jest natomiast fakt, że propozycje Poppera oraz jego wnioski dotyczące wartości poznania naukowego stanowią nie tylko opozycję względem fundacjonizmu, lecz przede wszystkim okazują się istotnym przykładem stanowiska falibilistycznego ${ }^{24}$.

Wydaje się, że przekonanie, iż poznanie naukowe charakteryzuje przymiot prawdziwości (w sensie klasycznym), co oznacza (w pewnym uproszczeniu), że formułowanym przez teorie naukowe propozycjom odpowiada rzeczywisty stan rzeczy, stoi u podstaw redukcjonistycznych modeli naturalizacji. Stanowi to ich istotne „obciążenie” filozoficzne. Choć oczywiście nie można uznać fallibilizmu za pogląd przeciwny w stosunku do realizmu naukowego, to jednak konfrontacja wielu tez

${ }^{23}$ Zob. np. S. Hawking, L. Mlodinow, Wielki Projekt, przeł. J. Włodarczyk, Warszawa 2011, s. 12 .

${ }_{24}$ Zob. S. Haack, K. Kolenda, Two fallibilists in search of the truth, „Proceedings of the Aristotelian Society, Supplementary Volumes" 1977 vol. 51, s. 65. 
współczesnego realizmu prawnego ze stanowiskiem zawierającym podstawowe tezy fallibilistyczne ukazuje liczne problemy z nim powiązane. Idąc za Popperem, uznającym za fallibilizm pogląd, w myśl którego „możemy błądzić, a pytanie o pewność (lub nawet o wysokie prawdopodobieństwo) jest pytaniem błędnym"25, do owych podstawowych tez z pewnością zaliczyć należy przekonanie, że prawdopodobnie wszelkie naukowe opisy rzeczywistości fizycznej są błędne, a jedyną możliwością budowania ich w coraz wyższym stopniu adekwatnego opisu jest śmiałe stawianie hipotez, poddawanych próbom empirycznej falsyfikacji. Dzięki temu możliwe będzie asymptotyczne zbliżanie się do praw$\mathrm{dy}^{26}$, której ostateczne osiągnięcie nigdy nie stanie się jednak możliwe.

Propozycja Poppera zdaje się stanowić interesujący opis metodologii nauk nomotetycznych, takich jak fizyka. Problematyczne może być jednak uznanie jej adekwatności do opisu metod stosowanych przez przedstawicieli biologii, której status metodologiczny nie jest do końca jasny ${ }^{27}$. Niemniej jednak refleksje filozoficzne dotyczące natury poznania naukowego, jakie pozostawił Popper, wydają się w pełni adekwatne również w przypadku biologicznych nauk o zachowaniu (a być może także niektórych gałęzi psychologii). Jakie znaczenie mogą mieć one dla programów naturalizacji prawa?

Aby odpowiedzieć na powyższe pytanie, trzeba rozpocząć od zwrócenia uwagi na istotny aspekt prawa. Niezależnie, czy jego istoty będziemy poszukiwać poprzez analizę aktów prawnych czy ludzkich zachowań, posiada ono charakter uniwersalny. W ramach pierwszego, „klasycznego” spojrzenia stwierdzenie to jawi się jako oczywiste: jeżeli określone przepisy prawa obowiązują, to obowiązują wszystkie osoby

25 K. Popper, Open society and its enemies, Princeton University Press 2013, s. 491.

26 Tamże, s. 492.

27 Oczywiście takie sformułowanie może wzbudzać pewne wątpliwości, pojawia się wszak pytanie, czy metodologiczny status jakiejkolwiek dyscypliny można określić mianem ,jasnego". Niemniej jednak usprawiedliwieniem takiego stwierdzenia może być fakt, że klasyczna dystynkcja „nomotetyczny - idiograficzny” nie jest w pełni adekwatna dla opisu metod stosowanych w biologii. Pomimo iż zdecydowanie trafniejsze wydaje się uznanie, że jest to dyscyplina nomotetyczna, to jednak warto zauważyć, że biolodzy stosunkowo rzadko (w porównaniu np. z fizykami) formułują ogólne prawa, które co do zasady powinny być stosowalne powszechnie. 
należące do określonej grupy będące ich adresatami. Inaczej wygląda sytuacja z perspektywy nurtów realistycznych, chociaż również w ujęciu ich przedstawicieli prawo - pod postacią czy to emocji czy innych zjawisk mentalnych - okazuje się „czymś powszechnym”. Niemniej element „prawa w księgach” jest również w tym przypadku konieczny. Kluczową rolę powinien jednak odgrywać komponent naukowy, dzięki któremu możliwe ma stać się zgłębianie „istoty prawa”, na co nadziei upatruje Petrażycki, a w czym sensowność dyskursu filozoficznoprawnego chcieli widzieć realiści skandynawscy. Czy jednak owe nadzieje znajdują oparcie we współczesnej filozofii, której przedstawiciele podejmują refleksję nad wartością poznawczą nauki?

Jak każdy problem filozoficzny, również i to zagadnienie jest wciąż przedmiotem dyskusji, których konkluzywność jest wysoce wątpliwa. Konsensus co do niego jest oczywiście łatwiejszy do osiągnięcia, niż ma to miejsce w przypadku dyscyplin, takich jak etyka, metafizyka czy filozofia Boga, niemniej jednak istnieje kilka przeciwnych stanowisk, które wciąż posiadają wielu zwolenników. Nie jest celem niniejszego tekstu wyczerpujące ich przedstawienie, toteż ograniczymy się do dwóch z nich, stojących na przeciwnych biegunach dyskursu poświęconego charakterowi poznania naukowego. Są nimi, wspomniane już, realizm naukowy (w wersji „naiwnej”) oraz fallibilizm.

Jak wskazywano w części poświęconej prezentacji modeli „naiwnie redukcjonistycznych", wydaje się uprawnione stwierdzenie, że ich autorzy w tej kwestii byli zwolennikami realizmu naukowego. Uznawali wszak, że metody naukowe pozwalają realnie dociekać natury prawa utożsamionego z pewnymi zjawiskami natury częściowo przynajmniej materialnej (zależnie od poglądu w kwestiach metafizycznych). Ów program naturalizacji nie przewidywał jednak - jak się wydaje - istotnych kontrowersji z tym związanych. Skandynawscy realiści, chcąc wyrugować metafizyczne spekulacje $\mathrm{z}$ jurysprudencji i w konsekwencji uczynić z niej dyscyplinę spełniającą pozytywistyczne kryteria sensowności, narazili budowaną przez siebie wizję prawa na istotne zarzuty ze strony antypozytywistycznych filozofów nauki. Charakterystyczny dla empirystów logicznych fundacjonizm epistemologiczny, przejawiający się w szczególności 
w poszukiwaniu bezwzględnej podstawy poznania naukowego w obserwacjach, okazał się chybiony, co znalazło wyraz m.in. w pismach wspominanego już Poppera. Prawdopodobnie dlatego również i filozoficznoprawne refleksje Skandynawów utraciły znaczenie ${ }^{28}$, ich fundacjonizm był bowiem zbliżony do tego, który reprezentowali m.in. pozytywiści logiczni. Z punktu widzenia programów naturalizacji prawa ma to znaczenie o tyle, że - jak już sygnalizowano - twierdzenia naukowe mają stać się podstawą, niezawodnym fundamentem jurysprudencji.

\section{Podsumowanie}

Z powyższych rozważań płynie kilka spostrzeżeń. Przede wszystkim, w kontekście programów naturalizacji prawa istotną trudnością okazuje się nie tylko ich wewnętrzna niespójność (zob. omówienie koncepcji Holmesa i Petrażyckiego), lecz także konieczność zmierzenia się z podstawowymi problemami z zakresu filozofii nauki. Konfrontacja tych propozycji z faktem trudności jednoznacznej oceny wartości epistemicznej teorii naukowych stawia je wobec pewnych trudności. Brak dostrzegania wagi tych zagadnień okazuje się więc istotną słabością przedstawionych realistycznych nurtów w jurysprudencji. To natomiast prowadzi do wniosku, że filozofia nauki ma rzeczywiste znaczenie dla filozofii prawa. Owe dwie dyscypliny, których przedmioty zainteresowań - jak wspomniano we wstępie - mogą się jawić jako nieposiadające punktów zbieżnych, splatają się w ramach współczesnego realizmu prawnego, dziś jednego z najistotniejszych nurtów filozofii prawa, w zaskakująco wysokim stopniu.

\section{Bibliografia}

Holmes O., The path of the law, „Harvard Law Review” 1987 vol. 10 no. 8.

Motyka K., Petrażycki Leon, [w:] Powszechna encyklopedia filozofii, Polskie Towarzystwo Tomasza z Akwinu [wersja internetowa: http://www.ptta.pl/pef/ pdf/p/petrazycki.pdf]. 
Petrażycki L., Wstęp do nauki prawa i moralności [w:] tenże, O nauce, prawie i moralności: pisma wybrane, Warszawa 1985.

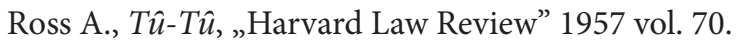

Ross A., Directives and norms, London 1968.

Stelmach J., Sarkowicz R., Filozofia prawa XIX I XX wieku, Kraków 1999.

Hart H. L. A., Scandinavian realism, „The Cambridge Law Journal” 1959 vol. 17 no. 2.

Załuski W., Game theory in jurisprudence, Kraków 2013.

Bjarup J., The philosophy of scandinavian legal realism, „Ratio Juris” 2005 vol. 18. Brożek B., Some remarks on the naturalization of law, Kraków 2010 (Studies in the Philosophy of Law, V).

Brożek B., Normatywność prawa. Szkic teorii (tekst dostępny na: http://biolawgy.files.wordpress.com/2010/06/normatywnosc.pdf).

Petrażycki L., O pobudkach postępowania i o istocie moralności i prawa, Warszawa 1924, s. 30-31.

Dalberg-Larsen J., Alf Ross and the sociology of law, „Scandinavian Studies In Law" 2005 vol. 48.

Leiter B., Naturalism In Legal Philosophy [w:] Stanford encyclopedia of philosophy, ed. E. N. Zalta, Stanford 2012, <http://plato.stanford.edu/entries/lawphil-naturalism/> (30.01.2014).

Llewellyn K., Some realism about realism: Responding to Dean Pound, „Harvard Law Review" 1931 vol. 44 no. 8.

Heller M., Przeciw fundacjonizmowi, [w:] tenże, Filozofia i wszechświat, Kraków 2006.

Reed B., How to think about fallibilism, „Philosophical Studies: An International Journal for Philosophy in the Analytic Tradition” 2002 vol. 107 no. 2.

Hawking S., Wielki Projekt, przeł. J. Włodarczyk, Warszawa 2011.

Haack S., Kolenda K., Two fallibilists in search of the truth, „Proceedings of the Aristotelian Society, Supplementary Volumes” 1977 vol. 51.

Popper K., Open society and its enemies, Princeton 2013.

\section{Projekt został sfinansowany ze środków Narodowego Centrum Nauki przyznanych na podstawie decyzji numer DEC-2012/04/A/HS5/00655.}

